\title{
Estimating Annual Precipitation in the Fenner Basin of the Eastern Mojave Desert, California
}

\author{
M.L. Davisson and T.P. Rose
}

\section{May 15, 2000}

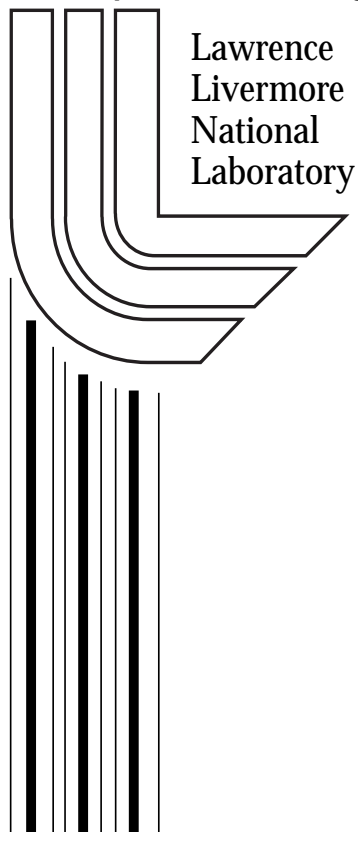




\section{DISCLAIMER}

This document was prepared as an account of work sponsored by an agency of the United States Government. Neither the United States Government nor the University of California nor any of their employees, makes any warranty, express or implied, or assumes any legal liability or responsibility for the accuracy, completeness, or usefulness of any information, apparatus, product, or process disclosed, or represents that its use would not infringe privately owned rights. Reference herein to any specific commercial product, process, or service by trade name, trademark, manufacturer, or otherwise, does not necessarily constitute or imply its endorsement, recommendation, or favoring by the United States Government or the University of California. The views and opinions of authors expressed herein do not necessarily state or reflect those of the United States Government or the University of California, and shall not be used for advertising or product endorsement purposes.

Work performed under the auspices of the U. S. Department of Energy by the University of California Lawrence Livermore National Laboratory under Contract W-7405-Eng-48.

This report has been reproduced directly from the best available copy.

Available to DOE and DOE contractors from the

Office of Scientific and Technical Information

P.O. Box 62, Oak Ridge, TN 37831

Prices available from (423) 576-8401

http://apollo.osti.gov/bridge/

Available to the public from the National Technical Information Service

U.S. Department of Commerce 5285 Port Royal Rd., Springfield, VA 22161 http://www.ntis.gov/

OR

Lawrence Livermore National Laboratory Technical Information Department's Digital Library http://www.llnl.gov/tid/Library.html 


\section{Estimating Annual Precipitation in the Fenner Basin of the Eastern Mojave Desert, California.}

\section{M.L. Davisson and T.P. Rose: Lawrence Livermore National Laboratory (LLNL)}

Metropolitan Water District (MWD) of southern California and Cadiz Inc. investigated the feasibility of storing Colorado River water in groundwater aquifers of the eastern Mojave Desert as a future drought mitigation strategy. This culminated in the public release of the Cadiz Groundwater Storage and Dry-Year Supply Program Draft EIR, which included pilot percolation studies, groundwater modeling, and precipitation/runoff analysis in the Fenner groundwater basin, which overlies the proposed storage site. The project proposes to store and withdrawal Colorado River water over a 50-year period, but will not exceed the natural replenishment rates of the groundwater basin. Several independent analyses were conducted to estimate the rates of natural groundwater replenishment to the Fenner Groundwater Basin, which was included in the Draft EIR. The U.S. Geologic Survey, Water Resources Division (WRD) officially submitted comments during public review and concluded that the natural groundwater replenishment rates calculated for the Draft EIR were too high. In the WRD review, they provided a much lower recharge calculation based on a Maxey-Eakin estimation approach. This approach estimates annual precipitation over an entire basin as a function of elevation, followed by calibration against annual recharge rates. Previous attempts to create precipitation-elevation functions in western Nevada have been difficult and result in large uncertainty (Hevesi et al., 1992). In the WRD data analysis, the effect of geographic scale on the precipitation-elevation function was overlooked. This contributed to an erroneous Maxey-Eakin recharge estimate.

LLNL has performed a more exhaustive review of precipitation-elevation data and find that precipitationelevation functions are best estimated by dividing data into longitudinal groups (Fig. 1). This is due to the following reasons: 1) the Sierra Nevada, San Gabriel, and San Bernadino mountains create a dramatic rain shadow effect whose intensity is greatest just east of the Sierra Nevada and decreases in an eastward direction; 2) winter storms originating from the Pacific Ocean have different trajectories and can produce locally intense snow and/or rain, but exclude other areas depending on its path; 3) summer storms originating from the Gulf of California produce more annual precipitation in the eastern Mojave Desert, but much less in the western Mojave. The effect of all these processes were absent from the WRD's estimates, even though these effects have been recognized and documented by previous researchers, including the U.S. Geologic Survey, WRD (Winograd and Thordarson, 1975). LLNL finds that annual precipitation in the western Mojave Desert is significantly less at higher elevations than in the Eastern Mojave Desert, and that recharge processes are not comparable nor translatable between these two areas. LLNL also finds that mathematical curve fits to precipitation-elevation data east of $116^{\circ} \mathrm{W}$ longitude delineates a regional precipitation/elevation effect, while a mathematical fit to four points adjacent or within the Fenner Basin delineates a local effect. The regional effect describes the precipitation/elevation function at a larger scale, whereas the local effect represents the function for the Fenner Basin (smallscale). The local effect predicts nearly 50\% more annual precipitation than the regional effect at higher elevations. Because the WRD did not consider geographic scale, they concluded that the four local data points generated an "unrealistic" result, and instead they used a mathematical fit similar to the regional effect in their Maxey-Eakin approach. This approach is incorrect. The local effect more accurately reflects local conditions in the Fenner Basin. Applying the regional effect to the Fenner Basin is an inappropriate matching of scales. LLNL results are presented in greater detail in a separate report (Davisson and Rose, 2000).

This work was performed under the auspices of the U.S. Department of Energy by University of California Lawrence Livermore National Laboratory under contract No. W-7405-Eng-48.

Davisson, M.L. and Rose, T.P., 2000, Maxey-Eakin methods for estimating groundwater recharge in the Fenner Watershed, southeastern, California. Lawrence Livermore National Laboratory UCRL-ID-139027, 13 pp.

Hevesi, J.A., Istok, J.D., Flint, A.L., 1992, Precipitation estimation in mountainous terrain using multivariate geostatistics. Part I. Structural analysis. Jour. Appl. Meteorol., 31, 661-676.

Winograd, I.J. and Thordarson, W., 1975, Hydrogeologic and hydrochemical framework, south-central Great Basin, Nevada-California, with special reference to the Nevada Test Site. U.S. Geol. Surv. Prof. Paper 712-C. 126 pgs. 


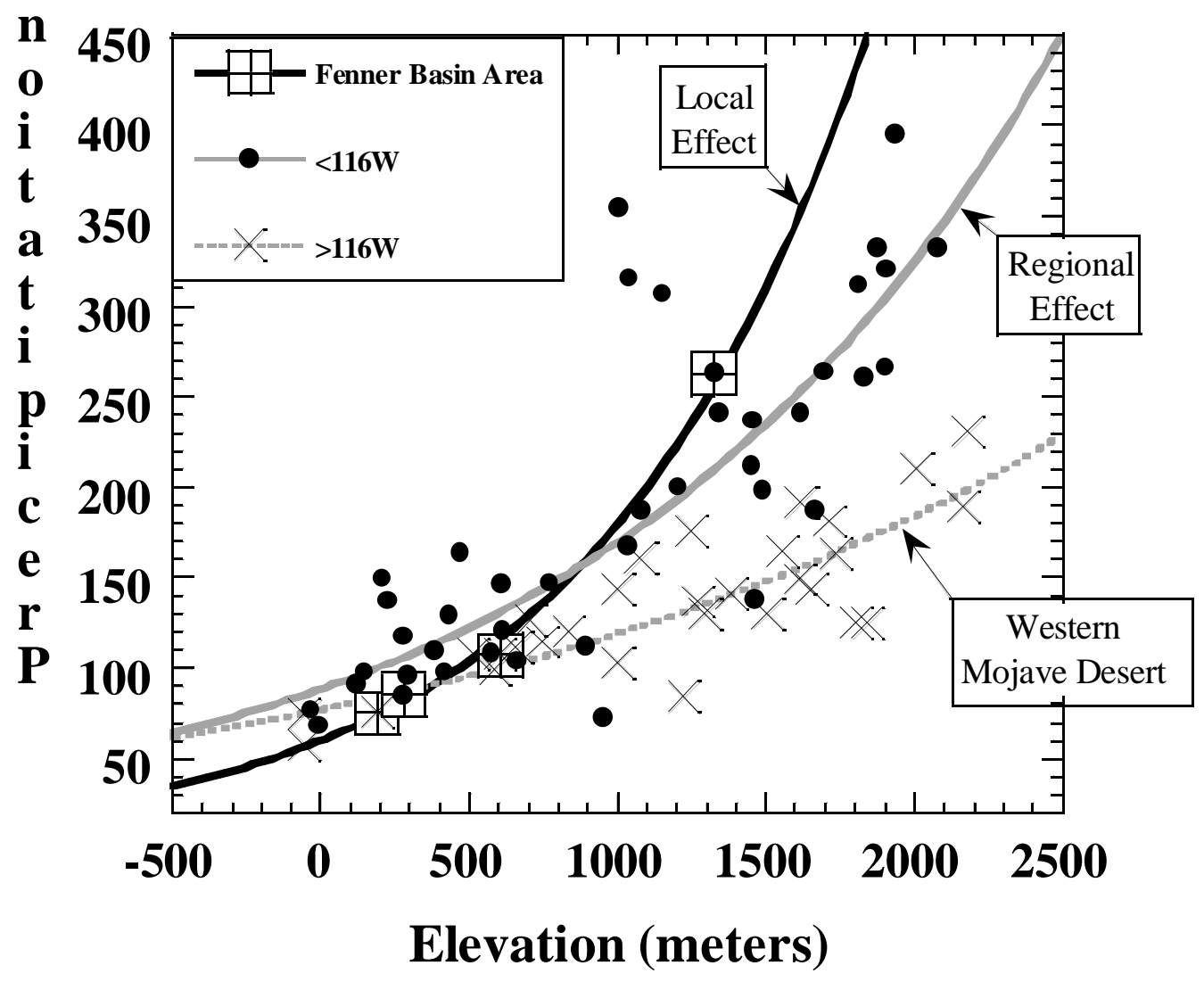

Figure 1. LLNL's precipitation-elevation curves. 